\title{
Epinephrine toxicity: an avoidable fatal complication due to iatrogenic overdose
}

\author{
Charu Neema ${ }^{*}$, Sahil Kapur ${ }^{2}$ \\ Assistant Professor ${ }^{1}$, Postgraduate student ${ }^{2}$, Dept. of Anesthesiology and Critical care, Sri Aurbindo \\ Institute of Medical Sciences, Indore,(M.P), India. \\ *Corresponding author: charu.neema@gmail.com
}

\begin{abstract}
Epinephrine is used as an additive to local anaesthetic solutions. Large doses of epinephrine used in local anaesthesia can cause toxic manifestations as in our case in a young patient posted for Tympanoplasty.
\end{abstract}

Keywords: epinephrine, epinephrine toxicity, local anaesthesia

\section{Introduction}

Epinephrine (Adrenaline) is the prototype drug amongst the sympathomimetics. It is a potent activator of $\alpha$ adrenergic receptors and also activates $\beta_{1}$ and $\beta_{2}$ receptors. It is added to local anaesthetic solutions to decrease systemic absorption and prolong the duration of action of the anaesthetic. $\alpha_{1}$ receptor mediated vasoconstriction decreases bleeding at the surgical site. $^{1}$

We report a case with epinephrine toxicity in a patient posted for Tympanoplasty under local anaesthesia and would like to discuss the issues regarding the use of epinephrine as an additive to local anaesthetic mixtures.

\section{Case report}

A 25 year old female, ASA grade one, weighing $60 \mathrm{~kg}$ was posted for Tympanoplasty under local anaesthesia. All routine investigations were within normal limits. Preoperative pulse rate and blood pressure were 78 per minute and $118 / 70 \mathrm{mmHg}$ respectively. Patient was premedicated with glycopyrrolate $0.2 \mathrm{mg}$, pentazocine $30 \mathrm{mg}$ and promethazine $25 \mathrm{mg}$ by intramuscular route. The surgeon infiltrated surgical site with $20 \mathrm{ml}$ of $2 \%$ lignocaine and $1 \mathrm{mg}$ of epinephrine. After a few minutes patient became restless and developed tachycardia (150-160 per minute), blood pressure had risen to $190 / 110 \mathrm{mmHg}$ along with complaints of headache and chest pain. ECG tracing showed ST depression and $\mathrm{T}$ wave inversion. Anaesthesiologist was then called upon.
Nitroglycerine spray $0.4 \mathrm{mg}$ via sublingual route was given and the same dose was repeated after 5 minutes. Blood pressure fell down to $140 / 90 \mathrm{mmHg}$. Headache and chest pain were relieved and the tachycardia settled after half an hour. ST depression was corrected in the 12 lead ECG taken subsequently. Blood sample was sent for Troponin I levels. The surgery was abandoned and patient was shifted to ICU for further management.

\section{Discussion}

Epinephrine toxicity presents as restlessness, throbbing headache, tremor, and palpitations. More serious reactions include cerebral haemorrhage and cardiac arrhythmias. ${ }^{2}$ Angina may be induced in patients with coronary artery disease. Pulmonary oedema is known to be caused by excess adrenaline. ${ }^{3}$ Significantly elevated Troponin T, CPK, CPK (MB) levels are noted. Long term side effects include tremors, muscle weakness, easy fatigability and shortness of breath on exertion.

It has been recommended in neck surgery that epinephrine in a concentration of 1:200,000 or 1:400,000 provide optimal initial haemostasis with minimal side effects, however, epinephrine 1:800,000 provided significantly less vasoconstriction. ${ }^{4} \mathrm{~A}$ dose of $3 \mathrm{mcg} / \mathrm{kg}$ up to a maximum of $200 \mathrm{mcg}$ has been considered as a safe dose in healthy individuals. ${ }^{5}$ In our case five times of this safe dose was used. Malamed 
recommended a maximum dose of $40 \mu \mathrm{g}$ epinephrine for a dental procedure per appointment in patients with cardiac disease. ${ }^{6}$

The duration of action of epinephrine is brief and hypertension may resolve spontaneously. Severe hypertension as in our case, require treatment with vasodilators such as nitroprusside or nitroglycerine. Treatment of systemic side effects with $\beta$ adrenergic blocking drugs may be followed by pulmonary oedema and irreversible cardiovascular collapse on account of the decreased ability of stressed myocardium to increase contractility and heart rate.

\section{Conclusion}

1. Monitored Anaesthesia Care will ensure better safety of the patient especially when a drug like epinephrine is added to the local anaesthetics. ${ }^{8}$

2. Risk to benefit ratio should be assessed before using epinephrine in cardiac patients.

3. Patient safety might be improved by expressing drug concentrations exclusively as mass concentration. ${ }^{9}$

4. Adding undiluted epinephrine ampoules in local anaesthetics in large doses is a major cause of such mishaps. Local anaesthetic solutions containing epinephrine in safer dilutions should be used. For example: 30ml Lignocaine 2\% with Epinephrine in 1:200000 dilution. ${ }^{10}$

\section{References}

1. Jastak JT, Yagiela JA. Vasoconstrictors and local anaesthesia: a review and rationale for use. JADA 1983;107:623-629. PMid:6355236

2. Katz R: Epinephrine and PLV-2: Cardiac rhythm and local vasoconstrictor effects. Anesthesiology.1965;26:619-623. http://dx.doi.org/10.1097/00000542-196509000-00006

3. Ersoz N, Finestone SC. Adrenaline-Induced Pulmonary oedema and its treatment. A report of two cases. Survey of Anaesthesiology. 1972;16(3): 216. http://dx.doi.org/10.1097/00132586-197206000$\underline{00015}$

4. Dunlevy TM, O'Malley TP, Postma GN. Optimal concentration of epinephrine for vasoconstriction in neck surgery. Laryngoscope 1996;106:14121414.

http://dx.doi.org/10.1097/00005537-199611000-

$\underline{00020}$

PMid:8914911

5. Milam SB, Giovannitti JA. Local anaesthetics in dental practice. Dent Clin North Am. 1984;28:493508.

PMid:6589180

6. Pharmacology of vasoconstrictors. In: Malamed SF, editor. Handbook of local anesthesia. 5th ed. St. Louis: Elsevier Mosby; 2004. p. 41-54.

7. Gourdine SB, Hollinbger I, Jones J et al. New York State Guidelines on the topical use of phenylephrine in the operating room. Anesthesiology 2000;92:859 -870 . http://dx.doi.org/10.1097/00000542-200003000$\underline{00030}$

8. American Society of Anesthesiologists: Position on Monitored Anesthesia Care. Park Ridge, IL, American Society of Anesthesiologists.1997, p 413.

9. Wheeler DW, Carter JJ, Murray LJ et al. The effect of drug concentration expression on epinephrine dosing errors: a randomized trial. Ann Intern Med. 2008Jan1;148(1):11http://dx.doi.org/10.7326/0003-4819-148-1200801010-00003

PMid:18166759

10. Nizharadze Net al. Articaine - the best choice of local anesthetic in contemporary dentistry. Georgian Med News.2011 Jan;(190):1523;Tbilisi State Medical University, Dental Clinic, Georgia. 